Research article

\title{
The Icelandic founder mutation BRCA2 999del5: analysis of expression
}

\author{
Evgenia K Mikaelsdottir ${ }^{1,2}$, Sigridur Valgeirsdottir ${ }^{3}$, Jorunn E Eyfjord ${ }^{1,2}$ and Thorunn Rafnar ${ }^{3}$
}

\author{
${ }^{1}$ Molecular and Cell Biology Laboratory, The Icelandic Cancer Society, Reykjavik, Iceland \\ ${ }^{2}$ Faculty of Medicine, University of Iceland, Reykjavik, Iceland \\ ${ }^{3}$ Iceland Genomics Corporation, Reykjavik, Iceland \\ Corresponding author: Thorunn Rafnar (e-mail: thorunnr@uvs.is)
}

Received: 24 Nov 2003 Revisions requested: 3 Feb 2004 Revisions received: 6 Feb 2004 Accepted: 10 Mar 2004 Published: 7 Apr 2004

Breast Cancer Res 2004, 6:R284-R290 (DOI 10.1186/bcr785)

(C) 2004 Mikaelsdottir et al., licensee BioMed Central Ltd. This is an Open Access article: verbatim copying and redistribution of this article are permitted in all media for any purpose, provided this notice is preserved along with the article's original URL.

\begin{abstract}
Introduction: A founder mutation in the BRCA2 gene (BRCA2 999de/5) accounts for 7-8\% of female breast cancers and for $40 \%$ of male breast cancers in Iceland. If expressed, the mutant gene would encode a protein consisting of the first 256 amino acids of the BRCA2 protein. The purpose of this study was to determine whether this mutant protein is produced in heterozygous individuals and, if so, what might be the functional consequences of mutant protein production.

Methods: The presence of BRCA2 999de/5 transcripts in fibroblasts from heterozygous individuals was assayed by cDNA synthesis and sequencing. The potential protein-coding portion of BRCA2 999de/5 was cloned into the pIND(SP1)/ V5-His vector and expressed in COS7 cells. The presence of the mutant protein in cell lysates from heterozygous fibroblasts and from COS7 cells was tested by a number of methods including immunoprecipitation, affinity purification with nickel-
\end{abstract}

coated agarose beads, Western blotting and ELISA, using antibodies to the N-terminal end of BRCA2, antiserum specific for the 16 nonrelevant amino acids at the carboxyl end and antibodies to fusion partners of recombinant proteins.

Results: The frequency of the BRCA2 999de/5 transcript in heterozygous fibroblasts was about one-fifth of the wild-type transcript; however, no mutant protein could be detected. Overexpression of BRCA2 999de/5 mRNA in COS7 cells failed to produce a mutant protein unless degradation by proteasomes was blocked.

Conclusion: Our results show that the protein product of BRCA2 999de/5 is extremely unstable. Therefore, an increase in breast cancer risk in BRCA2 999de/5 carriers is due to haploinsufficiency at the BRCA2 locus.

Keywords: BRCA2, BRCA2 999de/5, gene expression, haploinsufficiency, Iceland

\section{Introduction}

Mutations in BRCA1 and BRCA2 are associated with a high risk of developing cancer of the breast, of the ovaries and of other organs [1]. A large number of cancerassociated mutations in these genes have been described to date; however, few studies have directly probed the functional consequences of individual mutations [2-5]. One question that has thus rarely been addressed is whether the increased risk of cancer is simply due to the lack of one healthy copy of the gene (haploinsufficiency) or whether the gene produces a protein product that interferes with normal cellular processes.
Most nonsense (insertion/deletion) mutants are thought to result in unstable transcripts and in little or no mutant protein production [6]. Exceptions to this rule are found, however, also among the BRCA genes where proteins encoded by the following mutant genes have been detected: BRCA1 5382insC (Breast Cancer Consortium) and BRCA2 6174de/T [2]. Perhaps the most intriguing evidence for a potential functional role for truncated BRCA2 mutants comes from the observation that cancer risk is affected by the location of the mutation. Mutations in a central portion of $B R C A 2$, commonly termed the ovarian cancer cluster region, are thus associated with 
significantly higher risk of ovarian cancer but with lower risk of breast cancer than mutations in other regions of BRCA2 $[7,8]$. This variation in cancer risk is difficult to explain without invoking some effect of a protein product.

A single BRCA2 mutation accounts for $7-8 \%$ of breast cancers in Iceland [9]. The Icelandic mutation, a $5 \mathrm{bp}$ deletion in exon 9 starting at nucleotide 999 (BRCA2 999de/5), leads to a stop codon at nucleotide 1047 and to premature truncation of protein translation $[10,11]$. The truncated mutant protein is predicted to have the first 256 amino acids of wild-type (wt) BRCA2, followed by 16 outof-frame amino acids, and an estimated mass of about $35 \mathrm{kDa}$. The fact that BRCA2 999de/5 represents the only known founder mutation in lceland has set the stage for extensive population-based genetic and epidemiological studies on the effect of this mutation $[9,12,13]$. However, to date, no information has been collected on the potential expression of the BRCA2 999de/5 gene in heterozygous individuals.

The aim of the present study was to analyze expression of the mutated BRCA2 gene in BRCA2 999de/5 heterozygous cells to determine the functional consequences of BRCA2 999del5 at the cellular level.

\section{Materials and methods}

\section{Cells and cell lines}

Fibroblasts from individuals heterozygous for BRCA2 999del5 were grown in RPMI 1640 (Invitrogen Life Technologies, Carlsbad, CA, USA) supplemented with $20 \%$ FCS, $100 \mathrm{U} / \mathrm{ml}$ penicillin and $100 \mu \mathrm{g} / \mathrm{ml}$ streptomycin. Overexpressions were performed in COS7 cells (ATCC, Rockville, MD, USA) grown in DMEM (Invitrogen Life Technologies) supplemented with 10\% FCS, $100 \mathrm{U} / \mathrm{ml}$ penicillin and $100 \mu \mathrm{g} / \mathrm{ml}$ streptomycin.

\section{RNA isolation, cDNA synthesis and cloning of BRCA2 999del5}

Total RNA was isolated using the TRIZOL Reagent (Invitrogen Life Technologies). Three micrograms of total RNA were used for cDNA synthesis (First-Strand cDNA Synthesis kit; Amersham Biosciences, Hilleröd, Denmark). The open reading frame of BRCA2 999del5 was amplified using a primer pair where the $5^{\prime}$ primer was complementary to the Kozak sequence of the BRCA2 cDNA and the $3^{\prime}$ primer covered a 22 bp region prior to the putative stop codon of the BRCA2 999de/5 cDNA. The sequences were GTAAAAATGCCTATTGGATCC for the $5^{\prime}$ cloning primer, and AATGAATTCCCTGATGTTTTTC for the $3^{\prime}$ cloning primer.

The reaction mixture contained $2 \mu \mathrm{l}$ cDNA template, $2 \mathrm{mM}$ $\mathrm{MgCl}_{2}, 15 \mathrm{nmol}$ dNTPs, 15 pmol each primer and $2 \mathrm{U}$ Taq polymerase. The reaction proceeded at $95^{\circ} \mathrm{C}$ for $5 \mathrm{~min}$, followed by 40 cycles of $94^{\circ} \mathrm{C}$ for $1 \mathrm{~min}, 55^{\circ} \mathrm{C}$ for $45 \mathrm{~s}$ and $72^{\circ} \mathrm{C}$ for $1 \mathrm{~min}$, and finally heating to $72^{\circ} \mathrm{C}$ for $5 \mathrm{~min}$ and cooling to $4^{\circ} \mathrm{C}$.

The amplified BRCA2 product was isolated by electrophoresis on a $1 \%$ agarose gel, and then the DNA purified (GFX PCR DNA and Gel Band Purification Kit; Amersham Biosciences), cloned into pCR2.1-TOPO vector (Invitrogen Life Technologies) and used to transform TOP10 bacteria. Plasmids were purified from individual bacterial clones (Qiagen Plasmid purification Kit; Qiagen $\mathrm{GmbH}$, Hilden, Germany) and the clones were sequenced (ABI PRIZM Big Dye Terminator Cycle Sequencing Ready Reaction kit; Applied Biosystems, Foster City, CA, USA). After the deletion had been confirmed, the mutated DNA insert was excised from the TOPO-TA plasmid with Hindlll and Notl restriction enzymes (New England Biolabs, Beverly, MA, USA) and ligated into the pIND(SP1)/V5-His expression vector (Invitrogen Life Technologies).

\section{Transfections and activation of expression}

Cells were grown to 60-65\% confluency. Four microliters of FuGENE 6 reagent (Roche Applied Science, Hvidovre, Denmark) were added to $250 \mu \mathrm{l}$ serum-free medium and the mixture was incubated for $5 \mathrm{~min}$ at room temperature. After the addition of plasmid DNA ( $2 \mu \mathrm{g}$ per transfection), the mixture was incubated for $20 \mathrm{~min}$ at room temperature and then added to the cell cultures that had received fresh serum-containing medium. The cell cultures were allowed to recover after transfection for 24 hours, fresh medium was added and the cells were subsequently activated with ponasterone A (Invitrogen Life Technologies) at a concentration of $2.5 \mu \mathrm{g} / \mathrm{ml}$, as recommended by the manufacturer.

\section{Cell lysis, precipitations, and Western blotting}

Cells were lysed in RIPA lysis buffer containing 1\% Triton $\mathrm{X}-100,1 \%$ deoxycholic acid, $20 \mathrm{mM}$ Tris-HCl (pH 7.4), $150 \mathrm{mM} \mathrm{NaCl}, 2.5 \mathrm{mM}$ EDTA, 10\% glycerol and $10 \mathrm{mM}$ $\mathrm{Na}_{3} \mathrm{P}_{2} \mathrm{O}_{7}$, as well as 160 inhibitory units/ml aprotinin and $0.5 \mathrm{mM}$ phenylmethylsulfonyl fluoride. After lysis, 10\% of the lysate was removed (for use as a control) and the rest was incubated with antibody. For immunoprecipitations, $2.5 \mu \mathrm{l}$ primary monoclonal antibody or $5 \mu \mathrm{l}$ primary polyclonal antibody were used per precipitation. After the addition of antibody, the samples were subjected to gentle end-over-end shaking for $1-2$ hours at $4^{\circ} \mathrm{C}$. Subsequently, $50 \mu \mathrm{l}$ Protein G Sepharose beads (Amersham Biosciences) were added to each sample and the mixture incubated for a further 1 hour at $4^{\circ} \mathrm{C}$. The beads were washed with lysis buffer, the supernate was removed and $50 \mu \mathrm{l}$ of $2 \times$ sample buffer containing $\beta$-mercaptoethanol were added to the beads. The samples were boiled for $5 \mathrm{~min}$ and were centrifuged for $30 \mathrm{~s}$.

For precipitation of the overexpressed $6 \times$ His-tagged proteins, Ni-NTA Magnetic Agarose Beads (Qiagen 
$\mathrm{GmbH}$ ) were used. For purification of the $6 \times$ His-tagged proteins under native conditions, cells transiently transfected with pIND-BRCA2 999de/5 or with pIND$\mathrm{LacZ}$ were lysed in lysis buffer containing $50 \mathrm{mM}$ $\mathrm{NaH}_{2} \mathrm{PO}_{4}(\mathrm{pH}$ 8), $300 \mathrm{mM} \mathrm{NaCl}, 10 \mathrm{mM}$ imidazole, $1 \%$ Tween 20. Ten microliters of 5\% Ni-NTA Magnetic Agarose Bead suspension were added to the lysate and incubated for $1-2$ hours at $4^{\circ} \mathrm{C}$. The supernate was separated from the beads using a Qiagen 12-Tube Magnet (Qiagen) and the beads were washed several times with washing buffer containing $50 \mathrm{mM} \mathrm{NaH}{ }_{2} \mathrm{PO}_{4}$ $(\mathrm{pH} 8), 300 \mathrm{mM} \mathrm{NaCl}, 20 \mathrm{mM}$ imidazole, $0.05 \%$ Tween 20. The proteins were eluted from the beads with $25 \mu \mathrm{l}$ elution buffer containing $50 \mathrm{mM} \mathrm{NaH} \mathrm{PO}_{4}(\mathrm{pH} 8), 300 \mathrm{mM}$ $\mathrm{NaCl}, 250 \mathrm{mM}$ imidazole, $0.05 \%$ Tween 20, an equal volume of $2 \times$ sample buffer supplemented with $\beta$ mercaptoethanol was added to the eluates, and the samples were boiled for $5 \mathrm{~min}$ and centrifuged for $30 \mathrm{~s}$.

Purification of the $6 \times$ His-tagged proteins under denaturing conditions proceeded in exactly the same way except that the cells were lysed in a buffer containing $8 \mathrm{M}$ urea, $0.1 \mathrm{M}$ $\mathrm{NaH}_{2} \mathrm{PO}_{4}, 0.01 \mathrm{M}$ Tris- $\mathrm{Cl}(\mathrm{pH}$ 8), that the agarose beads with the bound $6 \times$ His-tagged proteins were washed with a buffer containing $8 \mathrm{M}$ urea, $0.1 \mathrm{M} \mathrm{NaH}_{2} \mathrm{PO}_{4}, 0.01 \mathrm{M}$ Tris- $\mathrm{Cl}(\mathrm{pH} 6.3)$, and that a buffer containing $8 \mathrm{M}$ urea, $0.1 \mathrm{M} \mathrm{NaH}_{2} \mathrm{PO}_{4}, 0.01 \mathrm{M}$ Tris- $\mathrm{Cl}(\mathrm{pH} 4.5)$ was used for elution of the proteins from the beads.

The precipitates and the lysates were separated by electrophoresis on gradient $6-18 \%$ polyacrylamide gels and blotted onto a Hybond-P membrane (Amersham Biosciences). The primary antibodies used in this study were: SC1 and SC3 rat monoclonal antibodies raised against the $\mathrm{N}$-terminal and $\mathrm{C}$-terminal sequences of BRCA2, respectively (a generous gift from D Bertwistle and A Ashworth); anti-V5 mouse monoclonal antibody (Invitrogen Life Technologies); anti-actin mouse monoclonal antibody (SDS); anti-BRCA2 rabbit polyclonal antibody raised against the putative out-of-frame residues at the C-terminus of BRCA2 999del5 (Bethyl Laboratories, Montgomery, TX, USA); and NCL-p53-DO7 mouse monoclonal antibody against p53 (Novocastra, Newcastle, UK). Secondary peroxidase-conjugated donkey anti-mouse and donkey anti-rabbit horseradish antibodies were purchased from Amersham Biosciences and peroxidase-conjugated goat anti-rat antibody was purchased from Pierce Biotechnology (Rockford, IL, USA). The ECL detection system (Amersham Biosciences) was used to produce images.

\section{Northern blotting}

Total RNA samples (about $15 \mu \mathrm{g}$ each) were separated by electrophoresis on a $1 \%$ agarose gel containing $2.2 \mathrm{M}$ formaldehyde and $0.02 \mathrm{M}$ 3-( $N$-morpholino)propane- visualized by UV. The gels were blotted onto Hybond-N+ membrane (Amersham Biosciences) and RNA was subsequently fixed by exposing the membrane to UV light for $5 \mathrm{~min}$. The BRCA2 999de/5 insert of the pINDBRCA2 999del5 plasmid was excised from the vector with Hindlll and Notl. Then $100 \mathrm{ng}$ insert were labeled using the ECL direct nucleic acid labeling system (Amersham Biosciences) and were used as a probe. The labeled probe was added to a hybridization buffer containing $0.5 \mathrm{M} \mathrm{NaCl}$ and $5 \%$ blocking agent, and the mixture was incubated with the membrane overnight at $42^{\circ} \mathrm{C}$. The images were developed using the $\mathrm{ECL}$ detection system (Amersham Biosciences).

\section{ELISA}

F96 Maxisorp immunoplates from Nunc (Roskilde, Denmark) were coated with cell lysates. The synthetic 16 amino acid peptide alone (the predicted 16 out-of-frame amino acid stretch of BRCA2 999del5), and the same peptide conjugated to keyhole limpet hemocyanin carrier protein were used as controls. Briefly, wells were coated with different dilutions $(1: 10,1: 100,1: 1000)$ of lysates prepared from the heterozygous fibroblasts on one hand, and from homozygous wt fibroblasts on the other hand, all made in duplicate. About $250 \mathrm{ng}$ synthetic peptides were used to coat each control well. All the samples were diluted in coating buffer containing $0.015 \mathrm{M} \mathrm{Na}_{2} \mathrm{CO}_{3}$, $0.035 \mathrm{M} \mathrm{NaHCO}_{3}$, and $0.003 \mathrm{M} \mathrm{NaN}_{3}$ (pH 9.6), which was also used as a blank. The same experiment was performed with the lysates of the COS7 cells transfected with pIND-BRCA2 999de/5 or with pIND-LacZ as control. The antibody against the putative 16 out-of-frame amino acid stretch of BRCA2 999del5 (dilution 1:2500) was used to detect the presence of the mutated BRCA2 protein. Preimmune serum was used as a control. The secondary antibody used was goat anti-rabbit alkaline phosphatase-conjugated antibody (DAKOCytomation, Glostrup, Denmark) diluted 1:3000 in PBS-0.05\% Tween 20.

\section{Proteasome inhibition}

To investigate whether the proteasome plays a role in the instability of BRCA2 999del5 protein, the proteasome inhibitor lactacystin was used to treat cells overexpressing pIND-BRCA2 999del5 or pIND-LacZ. Briefly, 24 hours after transfection, the cells were treated with ponasterone $A$ and consequently with lactacystin at a concentration of $10 \mu \mathrm{M}$ for different periods of time. The cells were thereafter lysed and subjected to electrophoresis on gradient 6-18\% polyacrylamide gel, transferred onto Hybond-P membrane and blotted with $\alpha-V 5$ or with the antibody against the nonrelevant residues of BRCA2 999del5 or SC1 antibody. Blotting with $\alpha$-actin was performed as a control for protein loading, and blotting with $\alpha$-p53 was performed as a control for proteasome inhibition. 


\section{Results \\ Expression of BRCA2 999del5 mRNA in heterozygous cells}

We tested whether mRNA encoding the mutated copy of the $B R C A 2$ gene was present in cells heterozygous for BRCA2 999de/5. cDNA was prepared from heterozygous fibroblasts, and an $822 \mathrm{bp}$ region, covering the open reading frame of $B R C A 2$ 999de/5, was amplified and cloned into TOPO plasmid. Sequencing of individual cDNA clones confirmed the existence of the mutant transcript. Out of 24 randomly chosen clones, five (approximately $20 \%$ ) had the $5 \mathrm{bp}$ deletion. Thus, although the mutant gene is transcribed, it is probable that the resulting mRNA is less stable than the mRNA transcript of the wt gene.

\section{No BRCA2 999del5 mutant protein could be detected in heterozygous cells}

The existence of mutated protein in fibroblasts heterozygous for BRCA2 999del5 was investigated by Western blotting. Two different antibodies were used for detection of the mutated protein: rat monoclonal antibody raised against amino acids 5-19 of human BRCA2 (SC1), and rabbit antiserum raised against the predicted 16 out-offrame amino acid stretch of BRCA2 999del5. Rat monoclonal antibody raised against amino acids 3386-3400 of human BRCA2 (SC3) and the SC1 antibody were used to detect wt BRCA2. There was no difference in the banding pattern of lysates of heterozygous samples compared with lysates with wt BRCA2 for any of these antibodies (data not shown). Immunoprecipitations with the SC1 antibody also failed to detect any mutant protein.

\section{Overexpression of BRCA2 999del5 in COS7 cells}

The inability to detect mutant proteins in BRCA2 999del5 heterozygous cells by Western blotting could be due to the lack of sensitivity of the antibody reagents. To test this possibility, the open reading frame of BRCA2 999de/5 was cloned into the pIND(SP1)/V5-His vector. COS7 cells were transfected with pIND-BRCA2 999de/5 and pVgRXR (Ecdysone-receptor plasmid), and 24 hours later expression of pIND-BRCA2 999de/5 was induced by ponasterone A. Parallel transfections with pIND-LacZ plasmid were used as positive control. Northern blot analysis showed that BRCA2 999de/5 RNA was expressed at high levels in transfected cells (Fig. 1). As the pIND plasmid contains sequences encoding a V5 epitope and a $6 \times$ His tag (poly-His), the cell lysates were probed for recombinant protein by affinity purification with either antiV5 antibody or Ni-NTA magnetic agarose beads. No overexpressed BRCA2 999del5 protein could be detected either in total cell lysates (Fig. 2a) or after purification on nickel-coated beads or precipitation with $\alpha$ V5 (Figs 2b and 2c, respectively). Thus, despite efficient transcription of the plasmids and clear detection of the LacZ protein, no mutant BRCA2 protein could be found.
Figure 1

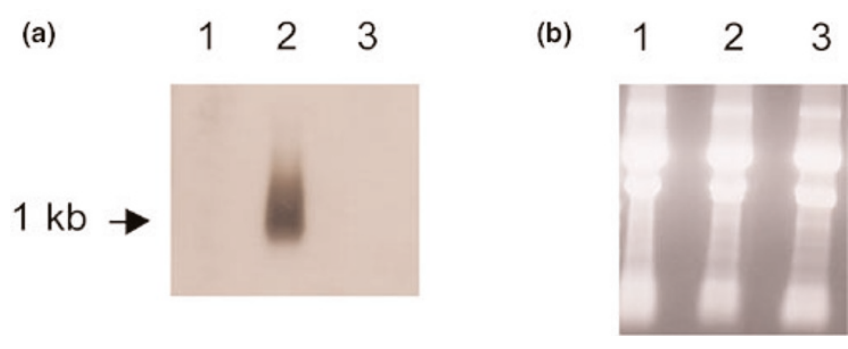

Overexpression of BRCA2 999de/5 mRNA in COS7 cells. The potential coding sequence of BRCA2 999de/5 was cloned into the pIND(SP1)/V5-His expression vector, transfected into COS7 cells and induced with ponasterone A: 1 , mock transfection; 2, cells transfected with pIND-BRCA2 999de/5; and 3, untransfected COS7 cells. (a) Expression of BRCA2 999de/5 was confirmed by northern blotting with a labeled BRCA2 999de/5 probe. (b) RNA samples that were used in northern blotting stained with ethidium bromide and visualized with UV light.

\section{ELISA fails to detect both endogenous and overexpressed mutant protein}

BRCA2 has proven to be a poor antigen for antibody production, hampering studies on the functional aspects of the protein. To try to gain a better handle on the BRCA2 999del5 protein product, a rabbit antiserum directed at the 16 out-of-frame amino acids of the putative protein was produced. An ELISA assay was used to try to detect mutant BRCA2 protein, employing this antiserum.

In the first set of experiments, wells were coated with lysates of heterozygous fibroblasts on one hand, and with lysates of wt fibroblasts on the other. The synthetic peptide used for antibody generation was used as a control. As shown in Fig. 3a, no mutant protein was detected in this assay. Furthermore, when lysates of cells transfected with pIND-BRCA2 999del5 were tested in the same assay, they also failed to detect any mutant protein (Fig. 3b).

\section{Detection of BRCA2 999del5 protein after proteasome inhibition}

After all the different attempts to detect the mutant BRCA2 protein had failed, we had still not been able to demonstrate whether this was due to extremely rapid degradation of the protein or simply to a lack of sensitivity by our detection methods. To try to distinguish between these possibilities, we performed proteasome inhibitions of COS7 cells overexpressing BRCA2 999del5.

In the first set of proteasome inhibition experiments, the cells were inhibited for $0,5,10$ and 20 hours, and cell lysis and protein purification were performed under nondenaturing conditions. Western blotting of p53 was used as a control for successful inhibition. No mutant BRCA2 protein was detectable in these samples (data not shown). 
Figure 2
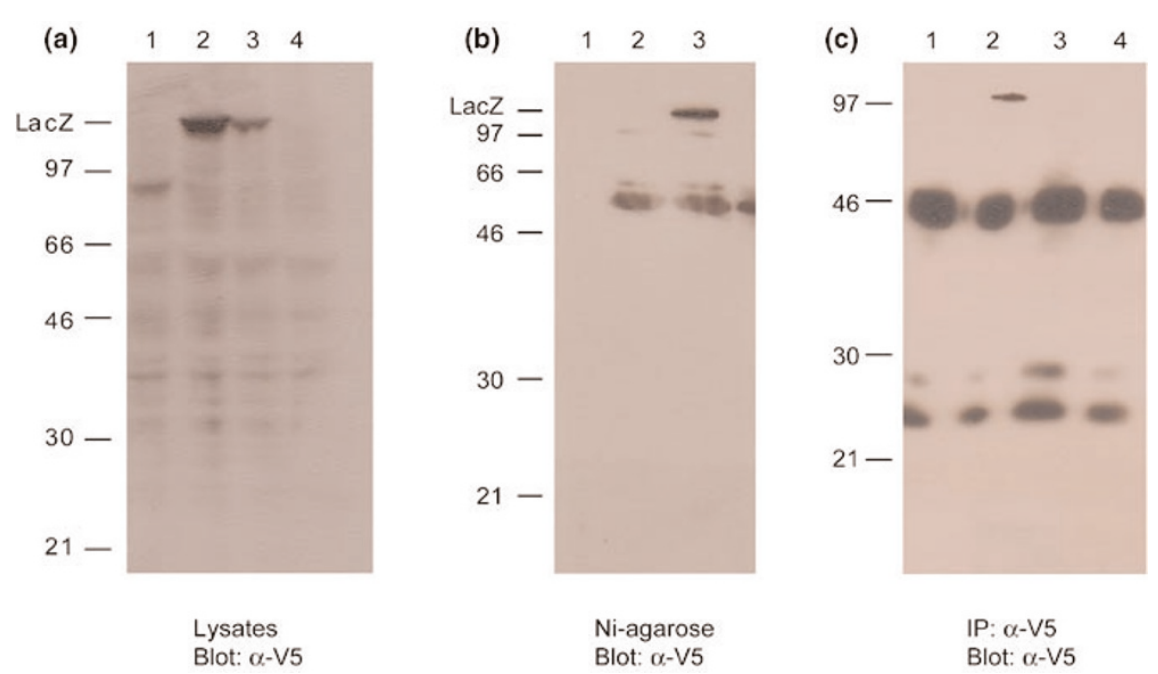

No mutant BRCA2 protein was detected in overexpression experiments. (a) Lysates of transfected COS7 cells were subjected to electrophoresis through 6-18\% gradient gel and blotted with an antibody against the V5 tag ( $\alpha$-V5): 1, untransfected cells; 2, pIND-LacZ transfected cells; 3, cells cotransfected with both pIND-LacZ and pIND-BRCA2 999de/5; and 4, cells transfected with pIND-BRCA2 999de/5. (b) Nickel-coated agarose beads were used to adsorb recombinant proteins under native conditions. The proteins were subjected to electrophoresis through $6-18 \%$ gradient gel and blotted with $\alpha-V 5$ : 1, untransfected COS7 cells; 2, cells overexpressing pIND-BRCA2 999de/5; and 3, cells overexpressing pIND-LacZ. (c) $\alpha$-V5 was used to precipitate recombinant proteins and for immunoblotting: 1 , untransfected COS7 cells; 2 , cells transfected with pIND-LacZ; 3, cells transfected with pIND-BRCA2 999de/5 without induction; and 4, cells transfected with pIND-BRCA2 999de/5 with induction.

Figure 3

(a)

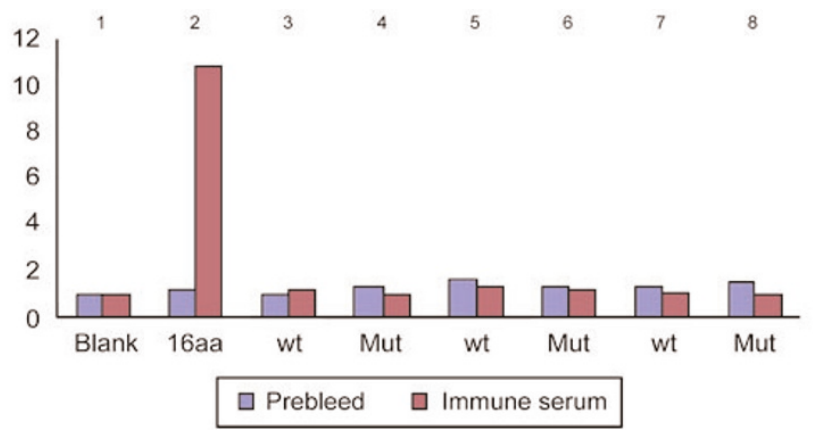

(b)

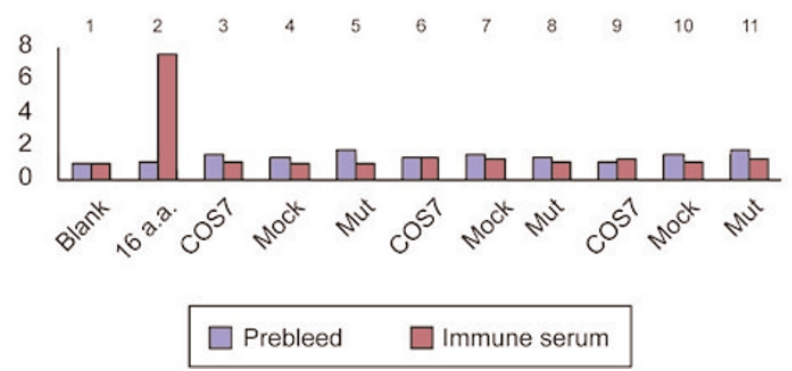

No mutant protein could be detected by ELISA. (a) Lysates of fibroblasts with wild-type BRCA2 (wt) and fibroblasts heterozygous for BRCA2 999de/5 (Mut) were tested for the presence of BRCA2 999del5 protein: bar pairs 3 and 4, lysates diluted 1:10; bar pairs 5 and 6, lysates diluted 1:100; bar pairs 7 and 8, lysates diluted 1:1000. (b) The same experiment was performed using lysates from untransfected COS7 cells (COS7), and COS7 cells overexpressing pIND-LacZ (Mock) or pIND-BRCA2 999de/5 (Mut): bar pairs 3, 4 and 5, lysates diluted 1:10; bar pairs 6, 7 and 8, lysates diluted 1:100; bar pairs 9, 10 and 11, lysates diluted 1:1000. The synthetic peptide, representing the 16 out-of-frame amino acids (a.a.) of BRCA2 999del5 and used to raise the antiserum, was used as a positive control.

There is a possibility that the protein is missing from the lysate because the recombinant protein is folded in such a way that the V5 epitope and the poly-His tag are inaccessible to the $\alpha-V 5$ antibody and nickel-coated agarose beads, respectively. Therefore, in a new set of experiments, the cells were lysed and the proteins purified under denaturing conditions. No protein could be detected in the lysates or after purification with nickel when the cells were not treated with proteasome inhibitors (Fig. 4a). However, when the cells had been treated with lactacystin for 5 hours, a $39 \mathrm{kDa}$ band (the expected size of recombinant BRCA2 999del5) emerged and showed a definite increase after 10 hours (Fig. 4b). These results show that even when overexpressed, the BRCA2 999del5 protein is rapidly degraded. It is therefore highly unlikely that this mutant protein has any functional effect in heterozygous individuals. 
Figure 4

(a)

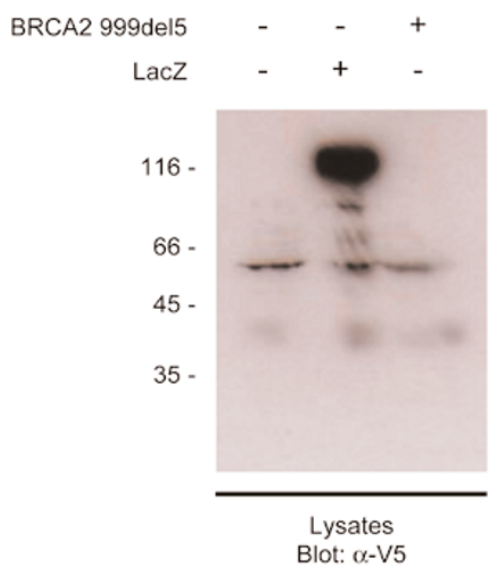

(b)

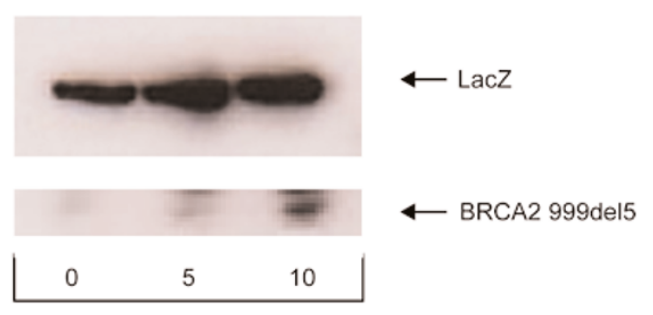

Proteasome inhibition (h)

$\mathrm{Ni}$-agarose

Blot: $\alpha$-V5

Detection of BRCA2 999del5 protein under denaturing conditions and after proteasome inhibition. (a) COS7 cells were transfected with pIND-BRCA2 999de/5 or pIND-LacZ without proteasome inhibition. Samples were treated under denaturing conditions. (b) COS7 cells were transfected with pIND-BRCA2 999de/5 or pIND-LacZ with proteasome inhibition. Samples were purified with nickel-coated agarose beads under denaturing conditions. Samples in both (a) and (b) were blotted with an antibody against the $\mathrm{V} 5 \mathrm{tag}(\alpha-\mathrm{V} 5)$.

\section{Discussion}

A large number of mutations in the BRCA2 gene have been identified to date that predispose to breast cancer, as well as to cancers in other organs. However, relatively few functional studies have been carried out on mutant BRCA2 proteins.

In the case of truncating mutations, it is often assumed that these alleles give rise to unstable transcripts that are detected and eliminated by a nonsense-mediated mRNA decay pathway $[14,15]$. In the cases where residual nonsense transcripts escape this elimination process, they may not be available to the translation machinery because they are not trafficked to the cytoplasm or may not be properly assembled into a closed loop conformation, precluding efficient translation initiation [6]. As a result, it has been generally accepted that most truncation mutants of the BRCA genes lead to haploinsufficiency.
It should be noted, however, that this rule is not universal and that mutant $B R C A$ gene products have been detected in at least two cases: BRCA1 5382ins $C$, which is located in exon 20 of $B R C A 1$, altering the reading frame after codon 1755 and terminating translation at codon 1829 [16] (our own investigation of the HCC1937 breast cancer cell line); and BRCA2 6174de/T, which is located in exon 11, causing protein truncation after codon 2002, and is detected by Western blotting as a protein of about $250 \mathrm{kDa}$ in the CAPAN-1 pancreatic cancer cell line [2].

In addition, indirect evidence suggests that in some cases mutant BRCA protein products may affect the oncogenic process. First, it has been firmly demonstrated that mutations in a $3.3 \mathrm{~kb}$ region in exon 11 , termed the ovarian cancer cluster region, are preferentially associated with ovarian cancer rather than with breast cancer [7,17]. The mechanism underlying this difference in phenotype is not understood, but the observation that this region coincides with the RAD51-binding domain of BRCA2 [18,19] suggests that mutant proteins might be involved. Second, a few studies have examined the functional effect of overexpression of truncated BRCA gene products. It was thus shown that several carboxyl-terminal truncated BRCA1 proteins conferred decreased susceptibility to apoptosis, impaired ability to suppress tumor growth in vivo and blocked the function of ectopically expressed BRCA1 [3]. Furthermore, a truncated BRCA1 mutant led to dominant negative effect of BRCA1, as shown by an increase in both tumorigenicity in vivo and chemosensitivity [5]. Taken together, these observations suggest that it may be necessary to study each mutation separately at the cellular level.

In the present study, we examined mRNA and protein expression of a BRCA2 gene carrying an Icelandic founder mutation. Mutant mRNA represented about $20 \%$ of the total BRCA2 transcript, demonstrating that the mutant message is present but is probably less stable than its normal counterpart. Notably, we were unable to find any traces of mutant protein product although several different techniques were employed.

Because negative results always leave open the possibility that the detection methods have failed, we went to considerable lengths in trying to overexpress mutant BRCA 999del5 protein in COS7 cells. BRCA2 999del5 is predicted to contain the first 256 amino acids of wt BRCA2 followed by 16 out-of-frame amino acids, and to have a mass of around $35 \mathrm{kDa}$. This means that although the putative protein lacks the nuclear localization signal found at the carboxyl terminus of the protein [2], it would probably be able to diffuse passively into the nucleus because the cutoff mass for passive diffusion through the nuclear pore is $65 \mathrm{kDa}[20,21]$. This possibility sets BRCA2 999del5 apart from larger known BRCA2 
mutants, which are kept in the cytoplasm due to the lack of nuclear localization signal.

We searched for the BRCA2 999del5 protein both in the cytoplasm and in the nucleus, but to no avail. Our results demonstrate that the BRCA2 999de/5 encoded protein is extremely unstable and not detectable in cell lysates except under conditions that block degradation by proteasomes. This extreme instability of the protein makes it highly unlikely that it has any functional effect in heterozygous cells and supports strongly the fact that the increased cancer risk of BRCA2 999de/5 carriers is solely due to haploinsufficiency.

\section{Conclusions}

In the present study, we asked whether the increased risk of cancer in BRCA2 999del5 carriers is simply due to haploinsufficiency or whether the gene produces a protein product that interferes with normal cellular processes. Although BRCA2 999de/5 mRNA was detected in heterozygous cells, we found no evidence of mutant protein in cell lysates. Furthermore, overexpression studies showed that the BRCA2 999del5 protein is extremely unstable. BRCA2 999del5-associated cancer risk is therefore most probably due to haploinsufficiency.

\section{Competing interests}

None declared.

\section{Acknowledgements}

This study was supported by grants from the Icelandic Research Council and from the Icelandic Cancer Society.

\section{References}

1. Welcsh PL, King MC: BRCA1 and BRCA2 and the genetics of breast and ovarian cancer. Hum Mol Genet 2001, 10:705-713.

2. Spain BH, Larson CJ, Shihabuddin LS, Gage FH, Verma IM: Truncated BRCA2 is cytoplasmic: implications for cancer-linked mutations. Proc Natl Acad Sci USA 1999, 96:13920-13925.

3. Fan S, Yuan R, Ma YX, Meng Q, Goldberg ID, Rosen EM: Mutant BRCA1 genes antagonize phenotype of wild-type BRCA1. Oncogene 2001, 20:8215-8235.

4. Brown MA, Nicolai H, Howe K, Katagiri T, Lalani el-N, Simpson KJ, Manning NW, Deans A, Chen P, Khanna KK, Wati MR, Griffiths BL, Xu CF, Stamp GW, Solomon E: Expression of a truncated Brca1 protein delays lactational mammary development in transgenic mice. Transgenic Res 2002, 11:467-478.

5. Sylvain V, Lafarge S, Bignon YJ: Dominant-negative activity of a Brca1 truncation mutant: effects on proliferation, tumorigenicity in vivo, and chemosensitivity in a mouse ovarian cancer cell line. Int J Oncol 2002, 20:845-853.

6. Mendell JT, Dietz HC: When the message goes awry: diseaseproducing mutations that influence mRNA content and performance. Cell 2001, 107:411-414.

7. Thompson D, Easton D: Variation in cancer risks, by mutation position, in BRCA2 mutation carriers. Am J Hum Genet 2001, 68:410-419.

8. Consortium SNIBB: BRCA1 and BRCA2 mutations in Scotland and Northern Ireland. Br J Cancer 2003, 88:1256-1262.

9. Tulinius $\mathrm{H}$, Olafsdottir $\mathrm{GH}$, Sigvaldason $\mathrm{H}$, Arason A, Barkardottir RB, Egilsson V, Ogmundsdottir HM, Tryggvadottir L, Gudlaugsdottir S, Eyfjord JE: The effect of a single BRCA2 mutation on cancer in Iceland. J Med Genet 2002, 39:457-462.

10. Tavtigian SV, Simard J, Rommens J, Couch F, Shattuck-Eidens D, Neuhausen S, Merajver S, Thorlacius S, Offit K, Stoppa-Lyonnet
D, Belanger C, Bell R, Berry S, Bogden R, Chen Q, Davis T, Dumont M, Frye C, Hattier T, Jammulapati S, Janecki T, Jiang $P$, Kehrer R, Leblanc J-F, Mitchell JT, McArthur-Morrison J, Nguyen K, Peng Y, Samson C, Schroeder M, Snyder SC, Steele L, Stringfellow M, Stroup C, Swedlund B, Swensen J, Teng D, Thomas A, Tran T, Tran T, Tranchant M, Weaver-Feldhaus J, Wong AKC Shizuya H, Eyfjord JE, Cannon-Albright L, Labrie F, Skolnick MH, Weber B, Kamb A, Goldgar DE: The complete BRCA2 gene and mutations in chromosome 13q-linked kindreds. Nat Genet 1996, 12:333-337.

11. Thorlacius S, Olafsdottir G, Tryggvadottir L, Neuhausen S, Jonasson JG, Tavtigian SV, Tulinius H, Ogmundsdottir HM, Eyfjord JE: A single BRCA2 mutation in male and female breast cancer families from Iceland with varied cancer phenotypes. Nat Genet 1996, 13:117-119.

12. Thorlacius $S$, Sigurdsson S, Bjarnadottir H, Olafsdottir $G$, Jonasson JG, Tryggvadottir L, Tulinius H, Eyfjord JE: Study of a single BRCA2 mutation with high carrier frequency in a small population. Am J Hum Genet 1997, 60:1079-1084.

13. Thorlacius S, Struewing JP, Hartge P, Olafsdottir GH, Sigvaldason H, Tryggvadottir L, Wacholder S, Tulinius H, Eyfjord JE: Population-based study of risk of breast cancer in carriers of BRCA2 mutation. Lancet 1998, 352:1337-1339.

14. Losson R, Lacroute F: Interference of nonsense mutations with eukaryotic messenger RNA stability. Proc Natl Acad Sci USA 1979, 76:5134-5137.

15. Schell $T$, Kulozik AE, Hentze MW: Integration of splicing, transport and translation to achieve mRNA quality control by the nonsense-mediated decay pathway [review]. Genome Biol 2002, 3:1006. [http://genomebiology.com/2002/3/3/reviews/1006]

16. Ruffner $\mathrm{H}$, Joazeiro $\mathrm{CA}$, Hemmati $\mathrm{D}$, Hunter T, Verma IM: Cancerpredisposing mutations within the RING domain of BRCA1: loss of ubiquitin protein ligase activity and protection from radiation hypersensitivity. Proc Natl Acad Sci USA 2001, 98: 5134-5139.

17. Gayther SA, Mangion J, Russell P, Seal S, Barfoot R, Ponder BA, Stratton MR, Easton D: Variation of risks of breast and ovarian cancer associated with different germline mutations of the BRCA2 gene. Nat Genet 1997, 15:103-105.

18. Mizuta $R$, LaSalle JM, Cheng $H L$, Shinohara $A$, Ogawa $H$, Copeland N, Jenkins NA, Lalande M, Alt FW: RAB22 and RAB163/mouse BRCA2: proteins that specifically interact with the RAD51 protein. Proc Natl Acad Sci USA 1997, 94: 6927-6932.

19. Wong AK, Pero R, Ormonde PA, Tavtigian SV, Bartel PL: RAD51 interacts with the evolutionarily conserved BRC motifs in the human breast cancer susceptibility gene brca2. J Biol Chem 1997, 272:31941-31944.

20. Gorlich D, Mattaj IW: Nucleocytoplasmic transport. Science 1996, 271:1513-1518.

21. Sarkisian CJ, Master SR, Huber LJ, Ha SI, Chodosh LA: Analysis of murine Brca2 reveals conservation of protein-protein interactions but differences in nuclear localization signals. J Biol Chem 2001, 276:37640-37648.

\section{Correspondence}

Thorunn Rafnar, Iceland Genomics Corporation, Snorrabraut 60, 105 Reykjavik, Iceland. Tel: +354 525 3600; fax: +354 525 3608; e-mail: thorunnr@uvs.is 